\title{
Qualitative Study: An Analysis of Pre-service Science Teachers' Understanding About Scientific Inquiry and Their Confidence in Inquiry-Based Science Pedagogy
}

\author{
Dr. Fayhaa Al-Momani \\ Dept. of Education, Najran University, P.O.Box1988, Najran 61441, KSA
}

\begin{abstract}
The study aimed to analyze the pre-service science teachers' (PSSTs) understanding about scientific inquiry and their confidence in Inquiry-Based Science Pedagogy. The study population composed of all the students of the 4th year/ 8th level enrolled with the program of pre-service teachers' preparation at the faculty of science and arts/ Najran University. Four sources of data was used: Structured focus group interviews; teaching performance observation card; Course content evaluation, In addition to a specific questionnaire developed according to the Likert-type scale (five-dimensional), which designed to support and confirm findings from the primary data sources. The data analyzed qualitatively and quantitatively then compared from all sources to generate assertions. The study appeared that most of the PSSTs have deficiency in understanding of the concept of scientific inquiry and some have misconceptions about it. And they have narrow and insufficient look about the nature of scientific inquiry nature, forms and levels, and its characteristics. Moreover, some PSSTs demonstrated fear and concern about the use of inquiry-based teaching in science teaching, while others showed their desire to use it in the future .The study indicate to failure of the teaching course to give the PSSTs adequate teaching skills and selfconfidence to teach the science that is based on scientific inquiry. The study recommended to introduce inquiry processes in the university science curricula, and design a course for science teaching centered on inquiry and the strategies based on it.
\end{abstract}

Keywords: Scientific Inquiry, pre-service science teachers', confidence in Inquiry-Based Science Pedagogy DOI: $10.7176 / \mathrm{JEP} / 10-5-07$

\section{Introduction}

Modern education attends to developing the learner from all mental (cognitive), sentimental and skill aspects, to achieve what the educators call for in educating and informing the students with the scientific Literacy of life, to become productive and effective in their community, able to deal with the developments of age and daily life issues and take the right decision toward them. In this regard, educators have perceived the importance to change the conception about how learner learns so that he will adopt his knowledge actively and be responsible for his learning, which called the scientific education reform movements to concentrate on a teaching method centered on the learner, by selecting methods of teaching that would enable the learner to actively participate in learning, by inquiring his thoughts and posing questions about them, experimenting them and analyzing their results, and engaging in hands-on, minds-on, and heads-on skills activities. From this perspective, the scientific inquiry has become a key target for learning in the third millennium.

For decades; and since 1950 scientific inquiry has been recognized as an essential element in the reform movements of science teaching. As well as, the official science education documents considered it the main element in the teaching and learning of science and the theme of understanding better the nature of science and a key component of the scientific literacy including: Benchmarks for Scientific Literacy (American Association for the Advancement of Science [AAAS], 1993), National Science Education Standards (NSES) (National Research Council (NRC), 1996), Next Generation Science Standards (Achieve, 2013), and Project 2061 (AAAS,1992). As recommended by the national science teachers association (NSTA) all science teachers from $\mathrm{K}-16$, to embrace the scientific inquiry approach in classrooms, as it would help students develop deeper understanding of sciences and scientific inquiry (NSTA, 2004). Likewise, the document of national institute for science and technology stated, "the inquiry through the genuine questions arising from the experiments of students is the central strategy for teaching sciences" (P2). As it provides the students with sorts of opportunities and experiences needed to develop the skills of control and analysis and synthesis through intellectual and practical activities at the same time (AAAS, 1993).

Activation of scientific inquiry in classrooms depends on the selection of it by the teacher as a way of teaching, and in this context; teacher's beliefs and conceptions about teaching and learning, and the way by which he looks at science, and scientific theory he is adopting, and the extent of his professional mastery, and understanding his role with the leaner will all effect and considerably the way of implementing science and his educational behaviors in classrooms and thus, on achieving the objectives of science teaching (Crawford, 2007; Ireland, Watters, Brownlee \& Lupton, 2012; Lotter, Harwood \& Bonner, 2007). This is what has been recommended by many conferences and reports about the teacher's teaching in order to improve education, as 
being the outlet in the field and informed about what is going on in classrooms in the changing world, including: report of "teaching and learning: realization of quality for all" (UNESCO, 2014) which recommended that the quality of educational system is measured by the level of its teachers, and the UNESCO international education conference, session 45 entitled "strengthening the role of teacher in a changing world" (UNESCO, 1996), and the report of "arising above the gathering storm" (National Academy of Sciences (NAS), National Academy of Engineering \& Institute of Medicine of the National Academies, 2007) which recommended the need for more well qualified math and science teachers. Therefore, teacher of science must be equipped with theoretical and practical knowledge, abilities and diverse skills in learning and education and technology, and be armed with positive morals and beliefs towards the profession. As, the depth of his knowledge and comprehension and behaviors would reflect automatically on his teaching practices (Zaytoon, 2010). Therefore, if we wanted to improve the educational system we have to attend to how science teacher is taught the art and methods of teaching.

On the other hand, teacher-training programs affect the dispositions and beliefs of pre-service teachers toward teaching in classrooms (Varma, Volkmann \& Hanuscin, 2009). Moreover, to enhance teachers training; Abell, Appleton and Hanuscin (2010) says, "The course of science methods is the primary basic means through which prospective teachers learn the teaching of sciences". Windschitl and Thompson (2006) indicated that preservice science teachers are the agents to transfer the practices of inquiry model to teachers. Consequently, emphasis should be directed to teachers' concepts about the nature of scientific inquiry to be ready to teach their students how to pose questions (questioning) and plan inquiries, implement the experiments and use the evidences in science, and also the ability to evaluate such evidences in building interpretations and connect them to creating sorts of opportunities and expertise needed to enable them to learn and build the meaning through their personal experiences by linking the new experiences with what they know or believe through exercising the scientific inquiry (Zaytoon, 2007).

Therefore, it is important for the teachers to understand what inquiry is, and know the benefits and challenges that face the use of this educational strategy, and to expand their experiences with the inquiry (Melville, Fazio, Bartley \& Jones, 2008). More importantly, is the teachers' recognition that their understanding of inquiry is a salient factor in the implementation of science by inquiry in classrooms. Therefore, if the teachers were able to understand the grounds for using the inquiry-based instructions and have the genuine expertise in scientific practices, then there will be a better chance to use it in their teaching (Magee \& Flessner, 2012; Morrison, 2014).

\subsection{Research Purpose and question}

In view of the advancement of cognitive research and development psychology, many countries of the world have incorporated the inquiry as one of their objectives in science curriculum, similarly, the KSA spearheaded the development of science curricula and their design based on global standards and what accomplished by researches have achieved in the field of curricula industry (Alshaya, 2009) in line with the KSA 2030 vision. Therefore, it had been keen to build and elevate the efficacy of teachers' performance by developing their capacities and competences in a manner that would serve the project philosophy built on the learner-centered learning using methods of research and inquiry.

And since the preliminary phase of teacher preparation starts from the university (college), and given its critical role in forming the beliefs about education among pre-service teachers and its effect on his dispositions towards the profession in general and teaching in classrooms in particular, and in pursuit by us in evaluating preservice teachers perception, of inquiry and teaching methods built on scientific inquiry and revealing the role of science teaching methods course and practical experience in forming better understanding, confidence and adequacy in practicing learning and education built on inquiry in the classrooms. With the aim to develop it in the future, this study came to analyze the perception of pre-service science teachers of scientific inquiry and existing methods of science teaching based on inquiry. Moreover, exploring the role of teaching science methods course and field experience in acquiring confidence in teaching the science built on scientific inquiry. Therefore, the research questions were:

- How do PSSTs define and characterize scientific inquiry?

- How do PSSTs enact their inquiry instruction when planning to teach?

- What do PSSTs understand about inquiry-based science teaching after concurrently completing the science education methods course and its associated science field experience?

- How the science methods course and its associated science field experience help PSSTs acquire skills and confidence in teaching inquiry-based science?

- To what extent do preservice special education teachers plan to incorporate inquiry instruction in their future science classrooms? 


\subsection{Research importance}

The question raised here, is how teachers can be assisted to understand the educational importance of nature of science inquiry NOSI and acquire confidence in teaching science based on scientific inquiry. This perhaps would help them to avoid negligence of the NOSI apparent in the teachers' educational decisions and to review previous literature in general. And this may facilitate concentrating the teachers' intent on boosting the teachers' understanding of scientific inquiry by developing methods to convey this perception to learners in consistent with contemporary constructivist views and reform movements of scientific education to achieve the education vision 2020 and the national visions 2030. In addition to providing a remedial plan to improve this perception and build confidence in teaching science among pre-service teachers may assist competent educational bodies to take practical executive steps towards the improvement of teaching. And in order to achieve that, starting point will be ensure the new teachers' perceptions, at the present time, about the inquiry-based scientific teaching methods and, how can they be changed. This is what this study pursues to redress.

\section{Theoretical framework: Science Inquiry}

Inquiry is considered one of the most repeated and common scientific notions in the literature of modern scientific education during the past twenty years, for being consistent with the scientific vision of the world and considered as the link between the individual understanding of the nature of science and scientific literacy (Zaytoon, 2010). This term is ascribed to many teaching models in science at the international level (NRC, 2000, 2007, 2012; Osborne \& Dillon, 2008; Tytler, 2007); however; there is no internationally fixed definition of the inquiry and the inquiry-based learning. linguistically; inquiry is defined as: "endeavor or request to obtain knowledge and information or truth through questioning" (Dictionary, 2017), and educationally, The National Science Education Standards (NSES) defined inquiry as: "a multiple-face activity involving the conduction of comments; questioning; studying of books and other sources of information to know what is actually known and review it in the light of empirical evidences; planning for inquiries; using of tools to gather data, analyze and explain them; proposing answers, explanations, forecasts; and delivery of results" (NRC, 1996, p23). In addition to the diverse methods by which scientists examine the natural world and their proposal for explanations based on evidences drawn from their work" (NSTA, 2004). Also, it's defined simply by the science standards for the next generation as: "whatever implies the phrasing of a question that can be answered through investigation (research) and it's one of the scientific practices basics" (NGSS website, Achieve, 2014). Therefore, inquirybased learning is defined as the use of scientific inquiry in classrooms, where the student achieve by themselves to comprehension of concepts, and at the same time the responsibility of their leaning shall be shouldered by them, it's a form of self-directed constructed learning where learning of students will be better according to the constructivism theory once they directly participate in their own learning (Glasersfeld, 1996). And defined by the researcher as: "the intended process of investigation (search) carried out by the learner in different ways during which diverse activities are practiced-intellectual, physical and collective- inside or outside the classroom, to present justifiable scientific explanations and answers based on empirical evidences for the scientific questions posed by the teacher or generated from the students themselves about the natural and unknown phenomena relative to her to develop her scientific knowledge and understand the natural world".

And, notwithstanding the multiplicity of definitions yet all of them agree with the basic five features of inquiry in classrooms provided for in the document NSES (NRC, 2000, p24).

1. Learner engages in scientifically oriented questions;

2. Learner gives priority to evidence in responding to questions;

3. Learner formulates explanations from evidence;

4. Learner connects explanations to scientific knowledge; and

5. Learner communicates and justifies explanations.

Consequently, the inquiry in classrooms might be complete- classrooms with all five basic features - or partially- classrooms lacking one or more of the inquiry basic features- also, inquiry must be seen from two different perspectives- that of the teacher's and the learner's, so science teacher must be able to use different inquiry-based teaching and learning strategies to enable the students to master the scientific concepts through inquiries, whereas, the learner must be able to design and conduct scientific inquiries and acquire and understand scientific knowledge through the scientific inquiry (NRC, 2000, p28). Additionally, inquiry-based teaching may differ in "magnitude of organization, direction, training provided by the teacher to students participating in the inquiry", as it progresses in the leaner's role from the simple to the complex, and from the direction to assumption of control by the student (Kuhn \& Peas, 2008). Thus, four types of inquiry can be indicated according by Tafoya, Sunal \& Knecht (1980):

- Confirmatory-Inquiry (CI): Traditional Hand-on inquiry, so students such as watched movie where the teacher is in control of the process of teaching and learning in all its different fields.

- Structured-Inquiry (SI): As cookbook-teacher centered, At this level of inquiry shall start the distribution of roles between the teacher and learner, yet the teacher role remains central and that of the 
learner's is simple and limited to forming conclusions and checking the information she has already studied. This type is often presented in teaching experiences offered in illustrative labs and prevailing in school and university labs as well.

- Guided-Inquiry (GI): Teacher and student share and divide the work, which would alter the teacher role and the mental growth of learner and thereby change the classroom educational environment with which will begin the formation of inquiry community.

- $\quad$ Opened-Inquiry (OI): Do as scientist-student centered, its most advanced levels, where the student has the active role in most areas, which is the ultimate purpose to set up and prepare the student as authentic researcher. Realizing thereby the vision of scientific education reform movements.

Through the above classification, scientific inquiry as continuum can be seen on the basis of the progressive role of the teacher and student therein, where the teacher moves between its types and shifts in roles effectively and freely between the levels. Figure 1

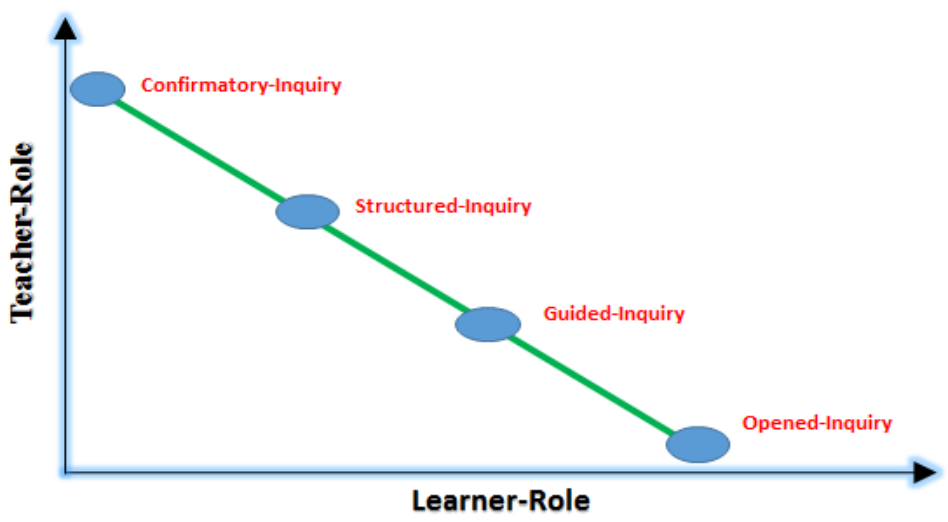

Figure 1. Inquiry continuum by learning levels ( Al-momani, F., 2019)

Figure 1 presents a visual organizational framework arranges inquiry types at levels in a joint hierarchy progresses from the simple to the complex according to the role of teacher and learner in the inquiry process and nature of activities carried out by each at every level thereof, to help thereby the teacher to integrate the scientific inquiry during teaching, in classroom, gradually without risks. And normally, to determine the level of inquiry required to use on the joint by the teacher and shifting at its levels (kinds) depends on the pedagogical (educational) objectives placed by the teacher and on factors and variables such as: his teaching skills; student aptitude; maturity; capacity; dispositions and trends. And this would impose on the teacher moving flexibly (back and forth) and continuously on the joint of inquiry and progressive and continuous practice of her to develop and advance such skills commensurate with the conditions and objectives contemplated. And, to get familiar with the inquiry fields and the role of the teacher and learner therein by the level of inquiry; review Table 1 (Bell, Smetana, \& Binns, 2005; Bonnstter, 1998).

Table 1: Determination of inquiry areas at each level/type and the role of teacher and learner.

\begin{tabular}{|c|c|c|c|c|c|c|c|}
\hline Level & $\begin{array}{c}\text { Type of } \\
\text { Inquiry }\end{array}$ & Topic & $\begin{array}{c}\text { Question/ } \\
\text { Problem }\end{array}$ & Materials & Design & $\begin{array}{c}\text { Results/ } \\
\text { Analysis }\end{array}$ & Conclusions \\
\hline 1 & $\mathrm{CI}$ & $\mathrm{T}^{*}$ & $\mathrm{~T}$ & $\mathrm{~T}$ & $\mathrm{~T}$ & $\mathrm{~T}$ & $\mathrm{~T}$ \\
\hline 2 & $\mathrm{SI}$ & $\mathrm{T}$ & $\mathrm{T}$ & $\mathrm{T}$ & $\mathrm{T}$ & $\mathrm{T} / \mathrm{S} *$ & $\mathrm{~S}$ \\
\hline 3 & $\mathrm{GI}$ & $\mathrm{T}$ & $\mathrm{T}$ & $\mathrm{T}$ & $\mathrm{T} / \mathrm{S}$ & $\mathrm{S}$ & $\mathrm{S}$ \\
\hline 4 & $\mathrm{OI}$ & $\mathrm{T} / \mathrm{S}$ & $\mathrm{S}$ & $\mathrm{S}$ & $\mathrm{S}$ & $\mathrm{S}$ & $\mathrm{S}$ \\
\hline
\end{tabular}

*T: Teacher; S: Student; T/S: Teacher \& Student

We deduce from table 1 above that whenever learners were responsible for posing questions and facing up to them, designing the inquiries or questions, extracting and transferring the learning, the inquiry will be more open, while the responsibility shouldered by the teacher will be much more, or more organizing or directing the inquiry on the other party of the continuum (NRC, 2000; Biggers \& Forbes, 2012). Which would transform the process of teaching into learning, and transferred the learning center from Teacher-Controlled to StudentControlled, whereupon the learner shall become responsible for himself and his learning to transform the learning stimulus from exogenous to endogenous, changing therewith the image of science from its traditional focus on science as mater to modern image that reflects the nature of science and scientific research with its skills, processes and methods. And, that through shifting from the traditional inquiry to open one. Figure 2 


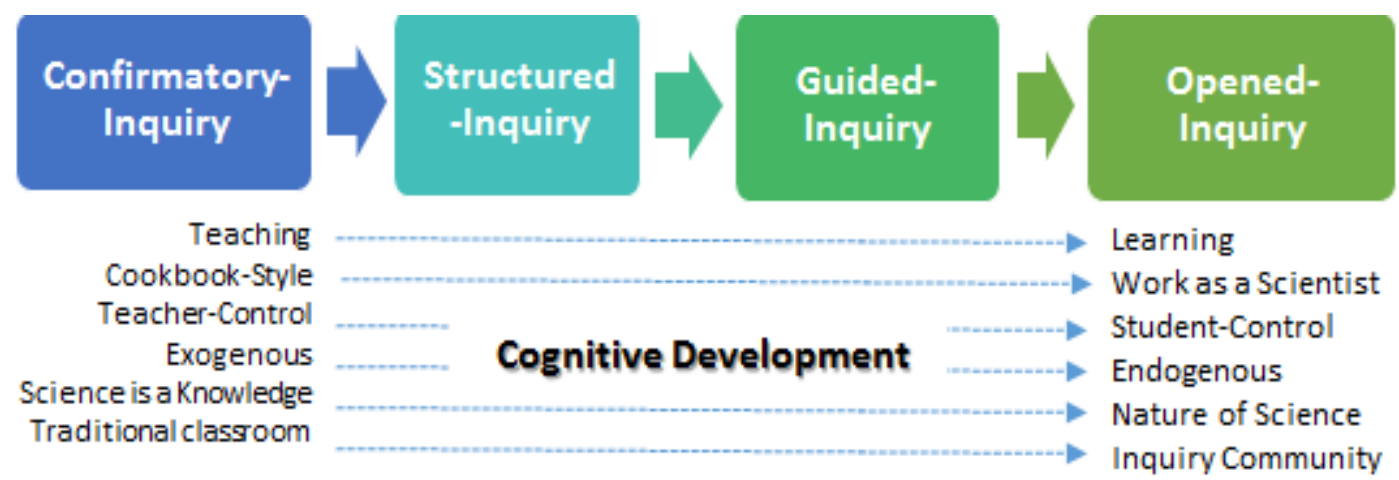

Figure 2. Transforming in Science Inquiry (Al-Momani, F., 2019)

It's clear from the foregoing that scientific inquiry approach is built on the principle of "teach me how to learn or learn how to learn", and thereby emulates the people's mind, nature and the natural human approach to understand the world around us. Thereby, the inquiry, in general, seeks to realize two objectives: provide the best understanding of the nature of science, and develop the cognitive capabilities to acquire the scientific Literacy (Bybee, 2006), through practicing scientific and intellectual activities; the learner integrates and unifies science process with scientific knowledge, and reasoning with critical thinking (Lederman, 1999). This approach would conform to the constructionists' perspective in that learning is a process of building expertise structures where previous knowledge and experiences would add new understandings, and that knowledge is built by the leaner self-activity (Piaget, 2013). The inquiry in science as design in engineer and technology (Zaytoon, 2010).

\section{Literature Review}

However, most researches about science teaching through the new teachers, focused up to now on confidence in teaching of teachers after completing the course of methods, field expertise, and specialized academic courses (Duran, McArthur, \& Hook, 2004; Hancock \& Gallard, 2004; Lee, Hart, Cuevas \& Enders, 2004). But, unfortunately, researches indicated to that $90 \%$ of pre-service teachers hadn't taught science based on open inquiry (Windschitl, Thompson, \& Braaten, 2008); and the inquiry-based learning is an exception not the rule in most classrooms (Capps \& Crawford, 2013; Smith \& Southerland, 2007). And therefore, and for not using the inquiry, many misconceptions take place about it among pre-service teachers. For example, pre-service teachers believe that there is a fixed global scientific method implemented step-by-step to reach scientific knowledge (Windschitl, 2004), and practicing activities is the inquiry in science, and that lab work parallels the scientific inquiry (Llewellyn, 2014). Also, most teachers believe that inquiry is a legend and leads to mess (Magee \& Flessner, 2012).

Therefore, and of course, many studies were conducted that were focused on teachers conceptions about the nature of scientific inquiry, and the results of such studies were contradictory. The results of some studies showed that many teachers have naïve and insufficient understandings about the nature of scientific inquiry as they view scientific knowledge as a fixed fact, and they have towards it absolute viewpoints, while other studies showed that some teachers have informed perspectives(Abd-El-Khalick, 2006; Dudu, 2014).

Although research has not directly addressed inquiry in science education, Yet, researchers revealed the obstacles and difficulties faced by pre-service teachers to activating the inquiry-based lessons in the classroom including: difficulty of pre- preparation or pre-processing of inquiry as it needs expansion in the material and pre-planning and raising different issues and high management for the class and for longer time, in addition to inadequate knowledge about the content, lacking of experience in research skills, paucity of practice and maladaptation with the inquiry activities, low level of cooperation, and unfavorable trend toward science (Davis, Petish \& Smithey, 2006; Kapucu, 2016). They also identified the dilemmas faced by science teachers to teach inquiry in the context of science methods course, and ascribed such dilemmas to the different definitions of inquiry in the literature of science teaching (Newman, Abell, Hubbard, McDonald, Otaala, \& Martini, 2004).

Moreover, analytical study (Carol \& Marlen, 2016), through which modification was introduced on science methods course in order to focus on the concepts of learning inquiry-based science, revealed about increased teachers' understanding of inquiry-based science teaching, and such conception is substantial to build confidence and effectiveness in teaching. Likewise, a study of (Varma \& Hanuscin, 2008) indicated to that teachers take up teaching methods based on reform if professionals directed them to it in the field experience. And generally, researches proved that the methods courses designed by inquiry and inquiry-based learning environment - from Guided to open inquiries - would develop teachers' understanding of inquiry-based science teaching, and able to shape practice among the new teachers, and Develop an appreciation for the benefits of teaching and learning science through inquiry in a constructivist environment (Akgul, 2006; Forbes \& Davis, 2010; Varma, Volkmann \& Hanuscin, 2009). This supports by (Biggers \& Forbes, 2012; Harrison, 2014; Salter \& atkins, 2013) who 
announce that inquiry methods in learning should be incorporated in all scientific courses, while concentrating on variations in the types of inquiry. This what was recommended by the study of (Avraamidou and ZembalSaul, 2005), that before we expect from pre-service beginner teachers how to teach science in this way, they should have firstly the opportunity to develop such aspects of scientific inquiry, and consequently, develop their own scientific education. Whereupon we can only set upon studying what strategies they use to translate their experience from exploring-learner of science to inquiry- teacher of science.

As a result of all the above, we find that scientific inquiry is necessary to teach science, and an important tool of it, and a substantial adequacy to science teacher he should acquire and develop well in his initial preparation program for the career, so the skills of inquiry prepares the teacher for critical thinking in problem solving and prompt them to learn science the lifelong. However, the main pillar for that depends on what the course of science teaching methods provides and how to practice in the field. Yet, previous literature indicated to that prospective teachers who graduate from the teachers' preparation programs are not ready and unconfident of understanding the inquiry or the inquiry-based methods of teaching in teaching of science. And, this what the researcher will deny or confirm through the study to present a new educational evidence about the reality of science teaching in the 21 st century and how teachers' preparation programs are fit to their purpose.

\section{Method and Procedures}

This chapter discusses the design of research and methodology followed to analyze the understanding of preservice science teachers of scientific inquiry and methods of inquiry-based teaching of science, therefore, this chapter involved two parts: the design and methodology of research.

\subsection{Part 1: Research Design}

This research has been designed an interactive qualitative study. Where, qualitative researches have the capacity to enable the researchers to identify the understandings expressed by individuals and meanings they make from their experiences by concentrating on specific individuals, and by concentrating on words instead of figures, and by inferential induction to analyze data and attain results (Maxwell 1996; Erickson, 1998). Also, qualitative research allows for the study of selected cases (as in scientific inquiry) elaborately, deeply, openly and flexibly through analyzing and interpreting the existing reality in the empirical realm (Patton, 1990) from the perspective of participants themselves, wherein the study was conducted in the natural environment of students, which is the classroom, at the applied schools and at micro-teaching workshops in which are present the features of the case under study. Moreover, this survey hasn't predetermined the level of understanding of the inquiry-based teaching among pre-service teachers, and depended on human tools in collecting data and identifying them with qualitative methods such as direct feedback, open questions and interviews and evaluation of the course, which would help understand and capture the perspectives of others and deal with the multiple facts inherent in the conceptions of individuals and which may differ on the basis of meaning drawn by each individual from its experience.

\subsubsection{Participants}

A number of (16) girl students teachers (pre-services science teachers) participated in the study, of the fourth year students, level (8) enrolled with the program of pre-service teachers' preparation at the science and arts college/ Najran University (physics/chemistry), and who are expected to graduate by the end of the first semester for the academic year (2017/2018), who have finished all the academic courses in the field of specialization, and also, who have passed the methods of sciences teaching and registered for the field experience and apply that at the government applied schools in Najran city in the KSA.

\subsubsection{Science Method Course}

Methods of science teaching is the course proposed to the students of education college (majoring in physics and chemistry) in the fourth year, level seven at a rate of (3) hours a week (42 hour during the semester), which aims to integrate theory with application to prepare pre-service students teachers for the teaching profession, academically, educationally, and professionally and provide them with skills and develop positive trends towards science teaching, the course addresses the nature of science, objectives of science teaching: types and levels, strategies of teaching learner-centered modern science, evaluation in science teaching, and planning for teaching. And to pass the course it's required to: an executive formulation for the behavioral objectives, preparation of a teaching plan, practice of micro-teaching, presentation and criticism of different educational attitudes, in addition to written exams. However, the course is taught by the faculty members at the university.

\subsubsection{Science Field Experience}

Period of field training for pre-service teachers at the applied schools is (12) weeks (one semester), during which pre-service teachers will watch applied lessons of the cooperating female teacher, and also, they will practice the teaching process in the classroom under the control of the cooperating teacher, which would aid in integrating their understanding of teaching strategies they had learned in the course of science teaching methods with those they are virtually applying in the classroom. And, at the same time they get training in the micro-teaching 
workshop inside the university one day every week in two groups under the direction of the practical education supervisor - member of the faculty majoring in science curricula and methods of science teaching - where the student shall practice teaching and implement effective teaching strategies in a virtual class environment for a short lesson (20 minutes), where her performance will be watched and evaluated, and feedback is given to improve and develop the performance in line with the learning objectives and program.

\subsection{Part 2: Research Methodology}

The research objective and questions was to direct data collection and analysis. It was as follows:

\subsubsection{Data Sources}

Four data sources were used to analyze the understanding of PSSTs of inquiry and inquiry-based methods of science teaching:

- Structured focus group interviews (discussion groups): focus training groups were used to capture the discussions reflected from female teachers students about their individual experience on the modeled teaching strategies in the course of science teaching versus those which were observed in the field in general, and also, to monitor their understanding of inquiry in teaching, and teaching of science by inquiry. However, they were interviewed at end of the semester in two groups each has (8) students. Discussions reflected from them were kept and registered. And, responses were encoded by the number of group and respondent (For example: G1-S4 represents Group 1-Student 4) to keep confidential the ID of participants. Texts from the focus groups were as the main source of data. Focus groups were held the beginning of the first semester 2017/2018 and continued to the end of semester (12 weeks) to capture the conceptions after completing the course of science teaching in a preceding semester and the field experience associated with this semester. The questions of interview were varying (open) in their nature to allow gathering specific information and reflected from the participants. Appendix 1

- Teaching performance observation card: it's a form to watch the students-teachers' direct performance in the classroom while conducting the micro-teaching. And, it aims to evaluate the teaching performance where the following are subject to observation: lesson plan; teaching strategies; content of the scientific material; evaluation strategies; teaching skills. The validity of feedback form content was affirmed by presenting it to a group of referees of experts and educators and in the field of science curricula and science teaching methods from NAJRAN University and in the field of analogy and assessment. And be certain of the form reliability through calculating the reliability of analysis across the individuals by calculating the HOLSTI coefficient which amounted to $(0.88)$, which is high and robust congruence coefficient- and that assured the researcher to use the said form.

- Course content evaluation: documents of the course were studied (such as the syllabus, description, assignments) to assess if the MOE recommendations, in teaching science through inquiry, have been incorporated into the syllabus and materials and how to verify them from the training groups' interviews.

- Questionnaire: the questionnaire for the study was designed to confirm the results drawn from the sources of initial data collection (Structured focus group interviews; teaching performance observation card; Course content evaluation), and thus, the questionnaire is an extra source of data specially designed for this study to complete the results that were obtained from the primary and secondary data sources and, other researchers had used similar method, for example: (Varma, Volkmann \& Hanuscin, 2009). However, the questionnaire was designed after looking into a group of tools used in previous surveys for the same purpose (Varma, Volkmann \& Hanuscin, 2009; Biggers \& Forbes, 2012). And, the questionnaire, composed of 44 paragraphs according to Likert Penta-Scale, contains five fundamental themes. Table 2

Table 2: The 44-point axes in the questionnaire

\begin{tabular}{|c|c|c|}
\hline Axis & Output & Paragraphs \\
\hline Nature of Science & $\begin{array}{l}\text { Pre-service teachers' understanding of the theoretical } \\
\text { foundations of the nature of science }\end{array}$ & $1-5$ \\
\hline Learning the inquiry in science & $\begin{array}{l}\text { The Pre-service teachers understanding the impact of survey- } \\
\text { based learning on student learning }\end{array}$ & $6-20$ \\
\hline $\begin{array}{l}\text { Teaching the inquiry in } \\
\text { science }\end{array}$ & $\begin{array}{l}\text { The pre-service teachers understanding for implementation and } \\
\text { effective survey practice in science teaching }\end{array}$ & $21-38$ \\
\hline Confidence in teaching science & $\begin{array}{c}\text { The confidence of pre-service teachers in their ability to teach } \\
\text { science }\end{array}$ & $39-41$ \\
\hline $\begin{array}{l}\text { Compatibility between } \\
\text { strategies designed in science } \\
\text { and field teaching methods }\end{array}$ & $\begin{array}{c}\text { Pre-service teachers' perceptions of the similarities between } \\
\text { science education strategies that were designed and taught in } \\
\text { the curriculum of science teaching methods and those observed } \\
\text { in the real field }\end{array}$ & $42-44$ \\
\hline
\end{tabular}


These tools together were used to answer the research questions and table 3 outlines these questions and strategies of data collection and mechanism of data analysis.

Table 3: Summary: Research questions, data source, data analysis

\begin{tabular}{|c|c|c|c|}
\hline $\mathbf{n}$ & $\begin{array}{c}\text { Research } \\
\text { questions }\end{array}$ & data source & method analysis \\
\hline 1 & Q1 & Structured focus group interviews; Questionnaires & $\begin{array}{c}\text { Quantitative/ } \\
\text { Qualitative }\end{array}$ \\
\hline 2 & Q2 & $\begin{array}{c}\text { Structured focus group interviews; Questionnaires; Teaching performance } \\
\text { observation card }\end{array}$ & $\begin{array}{c}\text { Quantitative/ } \\
\text { Qualitative }\end{array}$ \\
\hline 3 & Q3 & Structured focus group interviews; Questionnaires & $\begin{array}{c}\text { Quantitative/ } \\
\text { Qualitative }\end{array}$ \\
\hline 4 & Q4 & $\begin{array}{c}\text { Structured focus group interviews; Questionnaires; Teaching performance } \\
\text { observation card; Course content evaluation }\end{array}$ & $\begin{array}{c}\text { Quantitative/ } \\
\text { Qualitative }\end{array}$ \\
\hline 5 & Q5 & Structured focus group interviews & Qualitative \\
\hline
\end{tabular}

\subsection{Second: Procedures}

\subsubsection{Data analysis}

Current study adopted the qualitative research method. The texts which were obtained from the training focus groups deemed as the main data. Data analysis was set about by coding the data and defining a framework for it to be arranged in temporary categories such as the inquiry concept, the steps of the scientific inquiry ... to their responses on the basis of similarity and content of responses using the fixed comparison method, then indexing the results and organizing them in tables that facilitate interpretation of the results and their implications.(Appendix 2) This method was used previously in many researches including: analyzing the PSSTs understanding of the inquiry-based science teaching (Carole et al, 2016), and assessing the pre-service science teachers' understating of science teaching and learning (Haefner \& Zembal-Saul, 2004), and capturing the notions of the university students about the inquiry-based physics course (Duran, McArthur \& Hook, 2004).

In order to obtain repeated assurances for the emerging assurances related to the subject, and to ensure that the newly created assurances were based on the data and are credible, comparisons were conducted between the data from multiple sources (Structured focus group interviews; Questionnaires; Teaching performance observation card; Course content evaluation). So, the data were used to generate assurances and the opposite.

Also, students' responses to the questionnaire were analyzed quantitatively where arithmetic means, standard deviation for the affiliated paragraphs were calculated.

\section{Findings}

5.1 The PSSTS Understanding inquiry

Scientific inquiry for science teaching was examined through two themes: Understanding the theoretical underpinnings of the scientific inquiry, Understanding the instruction/ Fundamental about Scientific Inquiry.

5.1.1 Understanding the theoretical underpinnings of the scientific inquiry

Most of PSSTs reported that they have never been exposed to scientific inquiry and its procedures prior to the course of science education methods (SEM): "I have never performed inquiry for the purpose of this course" (G1-S3); "The first time I heard about inquiry was in the SEM course" (G2-S2). However, the PSSTs responses indicated that they have incomplete understanding of the scientific inquiry, and many of them stated that scientific inquiry is "an intentional exploration of the scientific concepts and new knowledge, carried out by the learner to investigate the unknown with guidance of the instructor", and he started with probing questions, where the frequency of repeating the word "probing questions" in the girl students' responses during answering about the concept of inquiry was around $66 \%$. The PSSTs understanding of scientific inquiry was limited to what occurs through the experiments and activities, and they didn't mention the role of thought and exploration processes in the inquiry:

"An anonymous term about which investigation is made, data collected and questions probed, and the students disclose them" (G1-S3); "Students' exploration of the scientific concept through the experiment or activity" (G1-S8); "Inquiry begins with something we want to know, or probing a question then reflect on this" (G2-S1).

Also, the PSSTs reported that the inquiry can be implemented in various curricula and not limited to science. Yet, scientific curricula are the most often user of scientific inquiry given the distinctive nature of science and based on experiments, activities and exploration of knowledge emerging from the environment and nature: "Inquiry is for science because science emulates the environment and nature" (G2-S6).

However, their answers to the quantitative questionnaire proved the students' understanding of the nature of science and its relation to inquiry, so the arithmetic mean of understanding the theoretical framework of science nature theme amounted to (4.1), the terms of which centered around the concept of science and its 
characteristics, such as pragmatism, objectivity, simplicity and relativity (temporary). With the exception of the statement that defined the target of science that it seeks after absolute truth, thereby the responses of girl students were negative, with an arithmetic mean of (2.07).

Reponses of PSSTs revealed that their knowing about exploring the scientific knowledge- which the scientific inquiry is one thereof - is limited, where the arithmetic mean for the term "science has a definite method to do it" was (4) a relatively high mean. In addition to their weak knowing about the inquiry forms- fair, desk, research, deductive - so the arithmetic mean for the term "searching for information in the reference journals and the internet and the library of the scientific inquiry forms" was weak and amounted to $(2,4)$. Furthermore, lack of their knowledge about the types of scientific inquiry needed to progressively move with students from implementer of experiments, as a cookbook, to investigator as scientists: "Inquiry is investigation with no types": (G2-S1)

In spite of that, it can be said that the PSSTs have good understanding of the theoretical framework of science nature and its relation with scientific inquiry; yet, they have incomplete notion about the scientific inquiry conception and some of its features in the classrooms, as the girl students' responses disclosed two features only of the inquiry's features: "Posing questions and building of notes", but they didn't recognize the rest of features notwithstanding they responded well to them in the quantitative questionnaire, where the arithmetic mean for the theme of inquiry learning came to (4.1).

5.1.2 Understanding the instruction/ Fundamental about Scientific Inquiry

Girls' students in focus groups specified the most important factor that the science teacher should consider on teaching by inquiry, from their perspective, which is to account for individual differences: "I think that the most important thing is to account for individual differences" (G1-S5), In addition to other considerations: adequate time, availability of tools, arrangement of classroom environment, knowledge about the subject of lesson.

Also, responses of the discussion groups disclosed the role of teacher in the inquiry-based classroom including: advisor, organizer, observer, director and provider with information, proposer of questions, assistant, presenter of feedback and assessor: "Teacher should direct the students and provide some comments" (G1-S4); "To give questions to reveal and organize the unknown piece of information" (G2-S4). And, they asserted these roles in responding to the quantitative questionnaire so the arithmetic mean of inquiry teaching in science was $(4,3)$, which focused on that the inquiry teacher of science must have deep scientific knowledge about the subject matter to pose scientific issues and problems so well and to welcome the questions of students and answer them and, also to have the skills needed for good teaching and be able to give her instructions about the scientific inquiry properly in classrooms including: manage open discussions, design and direct inquiry activities systematically, and provide the proper environment and manage time, support students' curiosity to reach scientific explanations supported with evidences to redress problems.

Yet, it's worth mentioning the terms related to the extent of their personal mastery of such roles such as the acquisition of adequate scientific knowledge to pose inquiry issues, expansion of knowledge and building of inquiries, confidence in their ability to pose questions and direct students during the activities, so the arithmetic mean was unsatisfactory and came to (2.07).

\subsection{The PSSTs Understanding of teaching and learning based of scientific inquiry}

Most girls students, in the discussion groups, concurred in that learning occurring upon focusing on inquirybased learning in science is a sort of directed discovery, cooperative active learning, and self-learning, as they described that it's: "flexible and easy learning" (G1-S3), and leads to discovery. However, improving practicing of it among the students, needs to: clarify the concept of inquiry as a strategy for students, provide suitable classroom environment, be practiced frequently by the teacher in classroom, to provide science coefficient in schools, and lessen the educational objectives in curricula. This appeared in an expression of a student who seemed hesitant and worried: "Improvement of students understanding of inquiry needs to lessen the objectives to be better applied" (G1-S6).

Moreover, most girl students in the discussion groups reported that implementation of inquiry among students is completed in steps in line somehow with the scientific methodology, and that it's linked to manual activities, yet they differed in the order of such steps:

"Divide students into groups then to give each group the tools" (G1-S1); "Prepare the tools-leave the students questioning- teacher directs the questions" (G2-S7); "Introduce the student to inquirywhat is required-I have to ask whether the student understood what is required-comment" (G2$\mathrm{S} 4)$; "Identify the unknown material, experiment, pose questions by the teacher, make an experiment, ..." (G2-S3); "Experiment, identify the materials, note the changes" (G1-S1).

Furthermore, no girl student referred to inquiry linkage to mental activities which are considered its differentiating base, also, their response lacked the necessity to be progressive in using scientific inquiry among students in classrooms at levels starting from the illustrative training to working as scientists.

And that supported their respective teaching plans which were observed while performing teaching by 
micro-teaching, where a considerable avoidance of scientific inquiry-based teaching, upon planning for teaching, was noticed, and though they used manual activities they planned to implement in the practical presentation provided by the teacher or a student with the assistance of teacher. In addition to their lower average scores in the theme of teaching skills in their practical performance which gauges how girls' students master them during the teaching performance.

And, girl students in the focus groups stated that learning and teaching science by inquiry have multiple positives to the teacher in various aspects- cognitive, skill and emotional-including:

"Strengthen scientific concepts" (G2-S1); "deliver the science properly, and create an opportunity for learning" (G1-S3); "Develop the learner and its capacities, uncover knowledge and expand it among them" (G2-S8); "Rely on oneself, engage the thought, motivate sound thinking with the student, and reinforce self-confidence" (G1-S5).

Furthermore, the PSSTs reported that scientific inquiry has positives to the teacher: "diversity and renovation would facilitate the teacher's role" (G2-S2); "prompt the teacher to make the students interested to obtain knowledge, augment the experience of teacher and make scientific material easier" (G1-S4); "deliver the abstract concepts" (G2-S3).

In spite of all that, the PSSTs mentioned the negatives of learning and teaching science by inquiry, including: "Lack of materials and equipment" (G1-S1); "Expending of effort, wasting of time, disorder" (G1S6); "Ambiguous for students which would increase their confusion, possibility to give knowledge erroneously" (G2-S4); "Consumption of time, the teacher encounters a problem when there is no reaction from the students, its difficulty" (G2-S7)

This supported the results of the questionnaire's quantitative analysis where the arithmetic mean of the paragraph "learning by inquiry presents great challenge to students and contains a lot of ambiguity" was high and came to (4.26); as well as the mean of paragraph "learning by inquiry is ineffective means to learn science in schools for the difficulty to obtain right answers from the activities", which amounted to (4.57).

\subsection{The PSSTs confidence in their ability for teaching inquiry-based science}

Answers of most students agreed in the two discussions groups, that there is agreement somehow between teaching the strategies already presented in the course of science teaching methods and those they applied in the field, and also, in the teaching skills practiced in classroom including: "standing before girl students and leading the class" (G1-S3); "posing questions to girl students and receiving answers" (G2-S2). Supporting their answers with examples on the strategies including: discovery, brainstorming, cooperative learning, inquiry. This supports the results of the quantitative questionnaire where the arithmetic mean of the terms that measure the extent of agreement came to (4.23). With the exception of the (G1-S7) student who said that there is no agreement between the strategies she studied in the course of science teaching methods and what she applied in the field and she attributed that to several reasons, saying: "the number of students and narrowness of classrooms wouldn't allow for applying many strategies".

And in this, all girl students in the discussion groups agreed unanimously that the course of science teaching methods has led to increased confidence in teaching science in general through: acquiring expertise and skills, accounting for individual differences, selecting the proper teaching method for each category of students, being familiar with the concepts and mastering the content, and also their confidence in themselves:

"That I'll become a successful teacher if I studied" (G1-S7); "confidence in science teaching an in myself has increased and I become ready to teach science" (G2-S4); "yes 100\%, it helped to integrate low-performer students with high-performers and in the exchange of expertise" (G1S5).

And on the contrary, responses of the PSSTs were negative altogether around the role of science teaching methods course in understanding the inquiry and processes of teaching and learning based on it, where some PSSTs informed us that they studied inquiry in the lecture and the brainstorming without any application on the part of the lecturer, and that the subject didn't take more than one lecture. Whereas, others said that they took the course by way of remote learning through the blackboard system in the form of pre-recorded lectures: "I was satisfied with the recorded lectures and didn't go to the college but for exams" (G2-S8). Also, the majority emphasized that they haven't practiced the inquiry nor received any assignments on it, and that the lecturer gave the theoretical aspect without application or even integration between the scientific inquiry-based strategies: "There is nothing, and we haven't conducted or implemented anything" (G2-S1); "Through performing the experiment of metals properties" (G1-S3).

This is what asserted by inspecting the course content where it was noticed that description of the course addressed the inquiry strategy as one of the course strategies numbering 17, and assigned to it two lectures at an average of (2) hours only, and was given separately from other relevant strategies such as problem-solving, learning cycle and BIBI model without linking it to scientific inquiry, though it is present in the course plan but disjointed. And in contrast, the textbook presented the theoretical material extensively with applied lesson on the 
directed inquiry. Furthermore, the evaluation tools approved in the course were limited to exams and developing a study plan on any teaching strategy and the student was not assigned to any performance or application concerning the scientific inquiry: "I haven't applied any experiment during the teaching methods course" (G1$\mathrm{S} 1)$. And thus, the course of science teaching methods didn't assist in understanding the scientific inquiry to teach science effectively.

On the contrary, girl students in the discussion groups asserted that field expertise has boosted their confidence in science teaching and understanding inquiry to teach science effectively: "Be familiar with the scientific material and examine in greater depth" (G2-S5); "Master the concepts and the sense of responsibility" (G1-S5); "self-confidence and class management" (G2-S8). Through practicing many teaching strategies including: mind maps, cooperative learning, directed inquiry, concepts charts, conducting experiments in groups. And the credibility of this is underscored by the result of quantitative analysis in the questionnaire where the arithmetic mean of this theme was (4.5), a high confidence grade. Also, the PSSTs suggested that studying the course of science teaching methods concurrently with the field training would give confidence in teaching of science more effectively, so the arithmetic mean in the quantitative questionnaire of this paragraph amounted to $(4,71)$.

5.4 The PSSTs planning to incorporate inquiry instruction in their future science classrooms

Most of students' responses in the focus groups asserted their wish to use inquiry-based teaching when teaching is exercised in the future:

"Yes, I'll use scientific inquiry because it's easier and flexible and works on strengthening the abstract concepts" (G1-S1); "For sure, I'll work on planning for teaching by inquiry as it helps grow thinking among learners, and makes learning more reliable" (G1-S5); "I think this, it's convenient for the teacher and helps her to give easily the piece of information and go deeper into it, and it makes the material (content) easier and enjoyable for students" (G2-S3)

Nonetheless, some students expressed their fear of using it: "Yes, I'll use inquiry-based teaching when I study because it's easy and flexible and helps grow thinking yet there are obstacles due to students crowding" (G2-S3). However, even others expressed their refusal of inquiry and unwillingness to use the inquiry-based teaching when teaching in the future: "No- it's difficult, the number of students is great, classrooms are narrow, and disorder" (G1-S7). And, though most of students think that they will use the inquiry-based teaching when teaching, yet they couldn't put in place a clear plan for how to use it or even describe a specific mechanism to implement in the classroom: "I'll implement it as I practiced it in the field" (G2-S7); "I'll read about it and train myself on it upon implementation" (G1-S5).

\section{Discussion}

This study aimed to analyze the PSSTs understanding of the scientific inquiry and confidence in inquiry-base teaching of science after passing the course of science teaching methods and going through the field experience.

Consequently, the PSSTs emphasized, in the study, that they hadn't known inquiry in the courses that preceded the course of science teaching, and this agrees with the study of (Windschitl, Thompson, \& Braaten, 2008). As deficiency appeared among most of the PSSTs in understanding the concept of scientific inquiry, and also, some had misconceptions about the notion scientific inquiry; so some thought that the inquiry is the empirical experiment; and it's the manual/practical activity which they carry out in the lab of science, and this agrees with the study of (Llewellyn, 2014), and it has fixed steps to reaching scientific knowledge, and this underscores what the study of (Windschitl, 2004) has concluded.

Also, it was found that the PSSTs have narrow and insufficient look about the nature of scientific inquiry nature, forms and levels, and its characteristics. Though they have good understanding of science nature, which forms the theoretical foundation of inquiry. We notice from that, non-formation of adequate understanding of the inquiry-based teaching in the cognitive environment among them and non-clear conception of the scientific inquiry steps so well and systematically, and there is a gap between the theoretical knowledge and practice of the scientific inquiry. And, this agrees with what the study of (Abd-El-Khalick, 2006; Dudu, 2014).

Moreover, some PSSTs demonstrated fear and concern about the use of inquiry-based teaching and put illogical arguments for that such as the crowded classrooms, as well as, they uncovered many difficulties and drawbacks that they may encounter upon using inquiry in classrooms, such as consumption of time and effort of the teacher and provocation of mess, and difficulty to prepare for it, and it needs deep examination of the content and mastery of the subject matter, and this agrees with the study of (Magee \& Flessner, 2012; Davis, Petish \& Smithey. 2006; Kapucu, 2016). However, this could be attributed to, as expressed by the PSSTs in the study, lacking to address inquiry cases and issues and the lack of effective inquiry practice during the study of science teaching methods course and, it's an exception in classrooms, and this agrees with the study of (Capps \& Crawford, 2013; Smith \& Southerland, 2007). And in contrast, other PSSTs showed their desire to use the scientific inquiry in teaching of science in the future, accounting for that by that the inquiry has many benefits 
and positives on the process of learning and teaching, yet it needs a special kind of teacher, with good mastery of content material, high pedagogical skills to control the class and learning process, in addition to pre-training. But none of the PSSTS could develop a clear conception of a mechanism to implement inquiry in teaching of science.

This may indicate to failure of the teaching course to give the PSSTs adequate teaching skills and selfconfidence to teach the science that is based on scientific inquiry as being a foundation for building the confidence and effectiveness in science teaching; as well as, training plan in the field experience is inadequate to implement inquiry in science teaching clearly and subjectively. Therefore, the PSSTs lacked self-efficacy and basic skills to teach science by scientific inquiry. And this agrees with the study of (Carole \& Marilyn, 2016; Appleton, 2006).

In this regard, we have to look into the content of teaching methods course and the mechanism of practicing the field experience among students, and the importance of guiding towards the inquiry and implementing it adequately through them, and also, to look into the time needed for the two courses, where the PSSTs suggested to give the two courses simultaneously in the same classroom rather than taking them consecutively. In addition to the importance of integrating the theoretical concepts of inquiry and the processes of practicing it through the course of science teaching methods and field expertise, to develop the teachers' understanding of scientific inquiry and boost their confidence in themselves and their ability to build inquiries and to apply the processes of inquiry-based teaching, which would provide significant avenues to exercise the inquiry-based teaching methods among pre-service teachers and, enhance their self-competency to teaching of science. In addition, this agrees with the study of (Akgul, 2006; Forbes \& Davis, 2010; Varma, Volkmann \& Hanuscin, 2009).

\section{Conclusions}

The results of analyzing PSSTs responses revealed the following, and also analyzing the curriculum tools and direct comment for teaching performance, in addition to analyzing the quantitative questionnaire:

- Source of misconceptions and naïve concepts about inquiry and its scientific nature is the course of science teaching methods and field expertise, on the assumption that girl students haven't been exposed to inquiry before the course of science teaching methods.

- Also, whenever the teacher was mastering his subject material he would be also effective in managing and organizing the inquiry.

- PSSTs encounter great challenge in bridging their knowledge of science with pedagogy because of moving from being a student knows and understands science to a teacher who directs the student to implement science.

- In order for the teachers to transfer their experiment about the scientific inquiry to their students; they must have good scientific education, skill in formulating the scientific problems and issues, and ability to planning and implementing the scientific inquiry commensurate with the level of inquiry used and the role of each the teacher and learner therein.

- Learning environment based on inquiry with its levels -from confirmation to open- would develop the understanding of teachers to teach inquiry-based science, and constitute the practice among new teachers, and change their views about the inquiry and the nature of scientific inquiry.

- The course of science teaching methods and field expertise is the base in building self-confidence and self-efficacy to teach the inquiry-based science.

- Concurrence of science teaching methods course with the field expertise would complement the theoretical side with practical exercise, and would give better results for effective teaching of practical inquiry in science classrooms.

- Practice and mastering the PSSTs for scientific inquiry facilitates decision-making about him to use it in the future during the service and success of career.

- Inquiry-Based Science Pedagogy still faces many difficulties including: limited classroom time; highvoltage for teacher; Causing chaos, and the difficulty of preparing him.

\section{Recommendations}

Prospective researchers must work with science sections to introduce inquiry processes in the university science curricula and measure its impact on the trends towards sciences and also on students' self-efficacy.

- Design a course for science teaching centered on inquiry and the strategies based on it, in which the learning environment is based on inquiry from Guided to open.

- The course of science teaching must provide practice and meta-cognitive analysis for inquiry issues in order to that the students understand the educational impacts of the basic theory about inquiry.

- Direct the professionals in the field expertise, about the scientific inquiry of all forms and levels progressive from the affirmative to the open, and to concentrate on the teaching skills of inquiry during the performance of teaching. 
- Mastery of science content and pedagogical knowledge in the preparation of science teachers must be affirmed to be perfect in scientific inquiry.

- Give the course of science teaching methods in a special scientific lab, in order to exercise the pedagogical skills and practical application of scientific issues and integrate between theory and practice.

- Study the circumstances existing in schools and classrooms that would support or hinder the implementation of inquiry for its considerable effect on learning science.

- Conduct further researches to determine the extent to which pre-service teachers insert the inquiry in the future professional practice.

\section{Acknowledgement.}

Thank you to all the students in the teacher preparing program at Najran University who participated in the experiment and expressed their willingness to cooperate and learn

\section{References}

Abd-El-Khalick, F. (2006). Over and over again: College students' views of nature of science. In L.B. Flick \& N.G. Lederman (Eds.), scientific inquiry and nature of science: Implications for teaching, learning, and teacher education (pp.389-425). Dordrecht, the Netherlands: Kluwer Academic Publishers.

Abell, S. K., Appleton, K., \& Hanuscin, D. L. (2010). Designing and teaching the elementary science methods course. New York, NY: Routledge.

Achieve. (2013). Next generation science standards: For states by states. [Online] Available: http://www.nextgenscience.org/next-generation-science-standards/ (December 20, 2018)

Achieve. (2014). Next generation science standards: For states by states. [Online] Available: http://www.nextgenscience.org/three-dimensions (November 24, 2018)

Akgul, Esra Macaroglu. (2006). Teaching science in an inquiry-based learning environment: what it means for pre-service elementary science teachers. Journal of Mathematics, Science and Technology Education, 2 (1), $71-81$

Alshaya, F. S. (2009). The development of science and mathematics education is a first step in building the knowledge society. Almaerifa Journal. [Online] Available: http://www.almarefh.net/show_content_sub.php?CUV=356\&Model=\&SubModel=138\&ID=284\&ShowAll $=$ On (April 15, 2017)

American Association for the Advancement of Science (AAAS). (1992). Project 2061. Washington, DC: AAAS.

American Association for the Advancement of Science (AAAS). (1993). Benchmarks for science literacy. NY: Oxford University Press.

Avraamidou, L., \& Zembal-Saul, C. (2005). Giving priority to evidence in science teaching: A first-year elementary teacher's specialized knowledge and practice. Journal of Research in Science Teaching, 42, 965-986

Bell, R. L., Smetana, L., \& Binns, I. (2005). Simplifying inquiry instruction. The Science Teacher, 72(7), 30-33

Biggers, Mandy \& Forbes, Cory T. (2012). Balancing Teacher and Student Roles in Elementary Classrooms: Preservice elementary teachers' learning about the inquiry continuum. International Journal of Science Education, 34 (14), 2205-2229

Bybee, R. W. (2006). Scientific Inquiry and Science Teaching. In L. B. Flick, \& N. G. Lederman (Eds.), Scientific Inquiry and Nature of Science: Implications for Teaching, Learning and Teacher Education (pp. 1-14). Dordrecht: Springer.

Capps, D. K. \& Crawford, B. A. (2013). Inquiry-based instruction and teaching about nature of science: Are they happenings? Journal of Science Teacher Education, 24(3), 497-526

Carole, K. L. \& Marilyn, Sh. (2016). An Analysis of Pre-service Elementary Teachers' Understanding of Inquiry-based Science Teaching. Science Education International, 27(2), 219-237

Crawford, B. A. (2007). Learning to teach science as inquiry in the rough and tumble of practice. Journal of Research in Science Teaching, 44, 613-642

Davis, E.A., Petish, D., \& Smithey, J. (2006). Challenges new science teachers' face. Review of Educational Research, 76(4), 607-651

Dictionary. (2017). Definition of Inquiry. [Online] Available: http://www.dictionary.com/browse/inquiry (April $15,2017)$

Dudu, Washington T. (2014). Exploring South African high school teachers' conceptions of the nature of scientific inquiry: a case study. South African Journal of Education, 34 (1)

Duran, L. B., McArthur, J., Hook, S.V. (2004). Undergraduate students' perceptions of an inquiry-based physics course. Journal of Science Teacher Education, 15, 155-171

Erickson, F. (1998). Qualitative research methods for science education. In B.J. Fraser \& K.G. Tobin (Eds.), 
International handbook of science education (pp. 1155-1173). London: Kluwer.

Forbes, Cory T \& Davis, Elizabeth A. (2010). Curriculum Design for Inquiry: Preservice Elementary Teachers' Mobilization and Adaptation of Science Curriculum Materials. Journal of Research in Science Teaching, 47 (7), 820-839

Glasersfeld, E.von. (1996). Introduction: Aspects of constructivism. In C. T. Fosnot (Ed.), Constructivism: theory, perspectives, and practices. New York: Teachers College Press.

Haefner, L.A., \& Zembal-Saul, C. (2004). Learning by doing? Prospective elementary teachers' developing understandings of scientific inquiry and science teaching and learning. International Journal of Science Education, 26(13), 1653-1674

Hancock, E., \& Gallard, A. (2004). Preservice science teachers' beliefs about teaching and learning: The influence of K-12 field experiences. Journal of Science Teacher Education, 15(4): 281-291

Harrison, C. (2014). Assessment of inquiry skills in the SAILS project. Science Education International, 25(1), $112-122$

Ireland, J., Watters, J., Brownlee, J. \& Lupton, M. (2012). Elementary Teacher's Conceptions of Inquiry Teaching: Messages for Teacher Development. Journal of Science Teacher Education, USA, 23, 159-175. DOI 10.1007/s10972-011-9251-2

Kapucu, Serkan. (2016). Guided Inquiry-Based Electricity Experiments: Pre-service Elementary Science Teachers' Difficulties. Journal of Education and Future year, 10, 71-93

Lederman, N.G. (1999). Teachers' understanding of the nature of science and classroom practice: Factors that facilitate or impede the relationship. Journal of Research in Science Teaching, 36(8):916-929

Lee, O., Hart, J.E., Cuevas, P., Enders, C., (2004). Professional development in inquiry based science for elementary teachers of diverse student groups. Journal of Research in Science Teaching. 41, No.10, 10211043

Llewellyn. D. (2014). Inquire within: Implementing inquiry-and argument-based science standards in grades 38 ( $3^{r d}$ edition). Thousands Oaks, CA: Corwin Press, Inc.

Lotter, C., Harwood, W. S., \& Bonner, J. J. (2007). The influence of core teaching conceptions in teachers' use of inquiry teaching practice. Journal of Research in Science Teaching, 44(9), 1318-1347

Magee, P., \& Flessner, R. (2012). Collaborating to improve inquiry-based teaching in elementary science and mathematics methods courses. Science Education International, 23(4), 353-365

Maxwell, J. A. (1996). Qualitative research design. California: Sage Publication.

Melville, W., Fazio, X., Bartley, A., \& Jones, D. (2008). Experience and reflection: Pre-service science teachers' capacity for teaching inquiry. Journal of Science Teacher Education, 19(5), 477-494

Morrison, J. A. (2014). Scientists' participation in teacher professional development: The impact on fourth to eighth grade teachers' understanding and implementation of inquiry science. International Journal of Science and Mathematics Education, 12(4), 793-816

National Academy of Sciences (NAS), National Academy of Engineering, and Institute of Medicine of the National Academies (2007). Rising above the gathering storm: Energizing and employing America for a brighter economic future. Executive Summary

National Research Council (NRC). (1996). National science education standards. Washington, DC: National Academy Press

National Research Council. (2000). Inquiry and the national science education standards: A guide for teaching and learning. Washington, DC: National Academy Press

National Science Teachers Association (NSTA). (2004). NSTA Position Statement: Scientific Inquiry. [Online] Available: http://www.nsta.org/about/positions/inquiry.aspx (April 15, 2017)

Newman, J. W., Abell, S. K., Hubbard, P. D., McDonald, J., Otaala, J., \& Martini, M. (2004). Dilemmas of teaching inquiry in elementary science methods. Journal of Science Teacher Education 15(4), 257-279

Patton, M. Q. (1990). Qualitative evaluation and research methods (2 ${ }^{\text {nd }}$ ed.). Newbury Park, CA: Sage.

Piaget, J. (2013). The construction of reality in the child. (82). Routledge.

Salter, I., \& Atkins, L. (2013). Student-generated scientific inquiry for elementary education undergraduates: Course development, outcomes and implications. Journal of Science Teacher Education, 24(1), 157-177

Smith, L., \& Southerland, S. (2007). Reforming practice or modifying reform? Elementary teachers' response to the tools of reform. Journal of Research of Science Teaching, 44(3), 396-423

Tafoya, E., Sunal, D., \& Knecht, P. (1980). Assessing enquiry potential: A tool for curriculum decision makers. School Science and Mathematics, 80, 43-48

UNESCO. (2014). UNESCO Report: Teaching and learning-Achieving quality for all. [Online] Available: https://un.org.au/2014/01/30/unesco-report-teaching-and-learning-achieving-quality-for-all/ (January 19, 2019)

UNESCO. (1996). Report to UNESCO of the International Commission on Education for the Twenty-first century, learning the treasure within. UNESCO publishing. 
Varma, T., \& Hanuscin, D. L. (2008). Pre-service elementary teachers' field experiences in classrooms led by science specialists. Journal of Science Teacher Education, 19(6), 593-614

Varma, T., Volkmann, M. \& Hanuscin, D. (2009). Preservice elementary Teachers' Perceptions of Their Understanding of Inquiry and Inquiry-Based Science Pedagogy: Influence of an Elementary Science Education Methods Course. Journal of Elementary Science Education, 21(4), pp. 1-22

Windschitl, M. (2004). Folk theories of inquiry: How pre-service teachers reproduce the discourse and practices of a theoretical scientific methods. Journal of Research in Science Teaching, 41(5), 481-512

Windschitl, M. \& Thompson, J. (2006). Transcending simple forms of school science investigation: The impact of pre-service instruction on teachers' understandings of model-based inquiry. American Educational Research Journal, 43(4), 783-835

Windschitl, M., Thompson, J., \& Braaten, M. (2008). Beyond the scientific methods: Model-based inquiry as a new paradigm of preference for school science investigations. Science Education, 92(5), 941-967

Zaytoon, Ayesh. (2010). Contemporary International Trends in Science Curricula and their Teaching Methods, Dar- Ashorauq publishers, Amman

Zaytoon, Ayesh. (2007). Constructivism Theory and Strategies for Teaching Science. Dar- Ashorauq publishers, Amman.

Zembal-Saul, C. (2009). Learning to teach elementary school science as argument. Science Education, 93(4), $687-719$

Appendixes

Appendix 1

Interview Questions (Focus Groups)

1. We talked a lot about the inquiry; if you want to explain it to someone who does not know, how can you know the scientific inquiry?

2. Is the inquiry specific to science or can it be implemented in any curriculum? How does "inquiry learning" relate to science?

3. What are the steps to implement the inquiry in the classroom?

4. What is the most important feature of the inquiry during its implementation with your students?

5. What is the role of the teacher in the inquiry-based classroom?

6. What factors should the teacher consider when teaching the inquiry?

7. From your point of view as a student, what are the pros and cons of inquiry learning in science?

8. From your point of view as a student, what are the pros and cons of inquiry-based teaching?

9. What type of learning is taking place when focusing on science-based learning?

10. In your opinion, how can students' understanding of the inquiry be improved for practice?

11. How can the inquiry be conducted with your students?

12. Describe how the inquiry model was presented during the Science Teaching Methods course.

13. Describe some of the inquiries done by you or Lecturer in the course of teaching science?

14. Describe some of the unique attitudes you observed during the Science Teaching Methods course that helped you develop your teaching strategies and improve your teaching skills in the inquiry?

15. How did the course of science teaching methods help you to understand the inquiry to effectively teach science?

16. How did the course of science teaching increase or decrease your confidence in science education?

17. How has field experience in science taught increased or decreased your confidence in science education?

18. . Are the strategies studied in the "Instructional Methods Course" consistent with the strategies applied in the field experience? Give me an example?

19. Do you think you will use inquiry-based teaching when you study? And why? How will you do that? 


\section{Appendix 2}

Analysis of qualitative data

Example of data encoding

\begin{tabular}{|c|c|c|}
\hline Category & codes & $\begin{array}{l}\text { \# of Individual in } \\
\text { focus group }\end{array}$ \\
\hline \multirow{6}{*}{$\begin{array}{c}\text { Define of } \\
\text { science } \\
\text { inquiry }\end{array}$} & $\begin{array}{l}\text { An anonymous term about which investigation is made, data collected } \\
\text { and questions probed, and the students disclose them }\end{array}$ & $\mathrm{G} 1-\mathrm{S} 3$ \\
\hline & I don't know & G2-S5 \\
\hline & $\begin{array}{l}\text { "Students' exploration of the scientific concept through the experiment or } \\
\text { activity }\end{array}$ & G1-S8 \\
\hline & $\begin{array}{l}\text { Inquiry begins with something we want to know, or probing a question then } \\
\text { reflect on this }\end{array}$ & G2-S1 \\
\hline & Inquiry is for science because science emulates the environment and nature & G2-S6 \\
\hline & To give questions to reveal and organize the unknown piece of information & G2-S4 \\
\hline
\end{tabular}

